\title{
MODEL PENINGKATAN INOVASI BERBASIS ORIENTASI PASAR, KNOWLEDGE SHARING DAN ORIENTASI PEMBELAJARAN TERHADAP KINERJA BISNIS
}

\author{
Moch Zulfa \\ Choirul Umam \\ Universitas Islam Sultan Agung Semarang \\ choirulumam1177@gmail.com
}

\begin{abstract}
Purpose in this study is to find and analyze the influence of orientasipasar, knowledge sharing and orientation learning of the performance of business with variable innovation as variable no intervening on industrial flour tapioca in kabupaten Pati. A population that used is the owner / entrepreneurs on industrial flour tapioca in kabupaten Pati of 162 people. Based on the results of the spread of the questionnaire directly to owners and with using a technique the sample collection simple random sampling, so obtained the sample of the of 66 respondents instrument the analysis is the path analysis with the program spss, where formerly undergone a validity and reliability and test the assumption classical. The results of testing shows that market orientation knowledge sharing and orientation of learning shown to have a positive influence to innovation and business performance. Innovation have a positive influence on the performance of business, can be defined that the more the owner / entrepreneurs be able to create new product innovation, the more one is increase the business performance produced .Innovation capable of being variable intervening between market orientation with the performance of business, it means the higher market orientation, The owner of the / employers could know, understand and answer the needs and hope from customers, so that the owner / entrepreneurs will be created product innovation new in increase the business performance. Innovation not capable of being variable no intervening between knowledge sharing with the performance of business. Innovation capable of being variable no intervening between orientation learning with the performance of business, Can be defined the higher the owner / entrepreneurs have the ability to learn, will it increases or insight new so will create product innovation new so increase the performance of business.
\end{abstract}

Keyword: orientation market, knowledge sharing, orientation learning, innovation and performance busines

\section{PENDAHULUAN}

Dalam era globalisasi persaingan pasar menjadi semakin ketat, sehingga perusahaan dituntut untuk memiliki kemampuan mengembangkan pilihan strategi di bidang manajemen pemasaran sehingga mampu beradaptasi dengan lingkungan yang semakin dinamis. Pada dasarnya dalam mengembangkan strategi bersaing yaitu mengembangkan strategi bagaimana bisnis akan mampu bersaing. Apakah sebenarnya yang menjadi tujuan, dan kebijakan apa yang akan diperlukan untuk mencapai tujuan-tujuan tersebut. 
Strategi harus direncanakan sehingga dapat mewujudkan keunggulan bersaing yang dapat bersaing dipasar. Apabila perusahaan dapat mendominasi pasar dan akan mempengaruhi kinerja bisnis perusahaan.

Kinerja bisnis dapat diartikan sebagai ukuran pencapaian tujuan organisasi (Daft, 2009 dalam Sulistiyani, 2013). Dalam meningkatkan kinerja bisnis yang semakin kompetitif, perusahaan harus bisa berusaha mempergunakan sumber daya yang dimiliki untuk dapat berinovasi.

Orientasi pasar adalah kemampuan perusahaan dalam mempelajari pelanggan, pesaing, dan kekuatan lingkungan untuk mendapatkan pemahaman tentang pasar secara berkesinambungan dan pengambilan tindakan pada pasar yang prospektif atau cerah (Day, 1994 dalam Sulistiyani, 2013).

Knowledge sharing(knowledge sharing) merupakan proses yang mencakupi penyebaran pengetahuan (Fitrasani, 2009). Dalam hal ini para pebisnis berkesempatan dan bebas menentukan cara baru untuk menyelesaikan usahanya dan berinovasi serta peluang untuk mensinergikan pengetahuan eksternal kedalam usahanya. Orientasi pembelajaran merupakan proses yang dilakukan perusahaan untuk memiliki keahlian dalam menciptakan, mempelajari dan mentransfer pengetahuan serta sikap dari perusahaan sebagai hasil dari pembelajaran masa lalu (Prakosa dan Ghozali, 2009). Salah satu cara untuk meningkatkan kemampuan disebuah perusahaan maka dari itu dengan meningkatkannya kemampuan perusahaan yaitu dengan menggunakan pembelajaran organisasi (Organization Learning). Kabupaten Pati merupakan salah satu daerah yang sebagian besar penduduknya mempunyai usaha tepung tapioka, seperti pada Ngemplak, Sidomukti dan Mojosemi yang sebagian besar penduduknya memanfaatkan ladangnya untuk ditanami bahan tepung tapioka. Dengan banyaknya para pengusaha tepung tapioka menjadikan persaingan bisnis usaha tersebut semakin kompetitif Perusahaan yang dapat menerapkan strategi yang maksimal dengan memanfaatkan informasi pasar akan tetap tumbuh dan berkembang, akan tetapi bagi perusahaan yang pengelolaannya masih kurang mampu memanfaatkan informasi pasar akan gulung tikar. Untuk mengetahui perkembangan usaha tersebut, maka akan dijelaskan beberapa contoh UMKM yang lama berdiri:

Tabel 1.1Pendapatan UMKM Industri Tepung (Dalam Ribuan)Kabupaten Pati (Pra Survey)

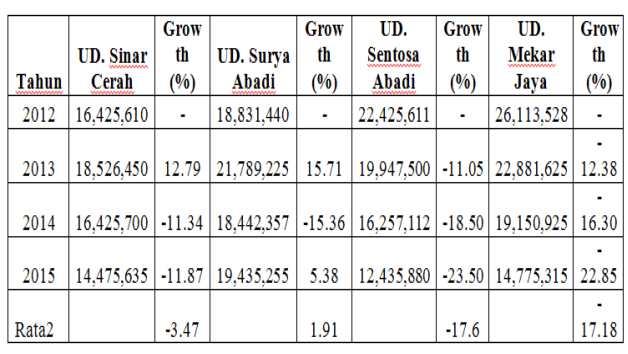

Sumber : Pengusaha UMKM Industri Kabupaten Pati, 2016

Berdasarkan tabel di atas, selama periode 2012 hingga 2015 pendapatan para pengusaha UMKM pada industri tepung yang tergolong besar di Kabupaten Pati secara keseluruhan mengalami penurunan, sehingga banyak perusahaan yang gulung tikar. Hal tersebut terlihat dengan pertumbuhan (Growth) perusahaan per tahunnya perusahaan yang terus menerus. Pada UD. Sinar Cerah rata-rata pertumbuhan pendapatan per tahunnya selama periode 2012-2015 menurun sebesar 3,47\%, sedangkan UD. Sentosa Abadi bahkan pertumbuhan menurun sebesar $17,6 \%$ dan UD. Mekar Jaya menurun sebesar $17,18 \%$. Peningkatan pendapatan yang tingkat pertumbuhan meningkat hanya pada UD. Surya Abadi pada tahun 2015 sebesar $1,91 \%$.

Penelitian tentang kinerja bisnis pernah dilakukan oleh beberapa peneliti, dimana pada penelitian Chasanah (2009), bahwa orientasi pasar mempunyai pengaruh positif 
terhadap kinerja karyawan.Sedangkan penelitian Dewi dan Dewi (2015) serta Salangka dan Datulong (2015) menunjukkan bahwa orientasi pasar mempunyai pengaruh terhadap inovasi.

dilihat dari permasalahan diatas, penelitian ini diberi judul: Model Peningkatan Inovasi Berbasis Orientasi Pasar, Knowledge Sharing dan Orientasi Pembelajaran Terhadap Kinerja Bisnis Industri Tepung Tapioka di Pati.

\section{KAJIAN PUSTAKA}

\section{Kinerja Bisnis}

Kinerja perusahaan yaitu kemampuan organisasi untuk mencapai sebuah tujuan dengan menggunakan sumber daya secara efektif dan efisien (Daft, 2000 dalam Sulistiyani, 2013).Kinerja perusahaan itu menggambarkan sejauh mana suatu organisasi mampu memenuhi kebutuhandan kepentingan organisasi untuk bisa bertahan hidup (Griffin, 2003 dalam Al-alak dan Tarabieh, 2011).

\section{Orientasi Pasar}

Orientasi pasar merupakan sebagai proses diri untuk menghasilkan dan memberika $\mathrm{n}$ sebuah infrmasi pasar dengan tujuan untuk menciptakan superior value bagi pelanggan (Lukas dan Ferrel, 2000 dalam Ghozali dan Prakoso, 2009).

\section{Knowledge Sharing}

Knowledge sharing atau berbagi pengetahuan merupakan proses yang mencakupi penyebaran pengetahuan. Knowledge sharing merupakan suatu metode untuk berbagi ilmu pengetahuan, teknik, pengalaman dan suatu ide yang mereka miliki kepada anggota lainnya (knowledge sharing) merupakan salah satu metode dalam knowledge management yang digunakan untuk memberikan kesempatan kepada anggota suatu organisasi,instansi atau perusahaan untuk berbagi tentang ilmu pengetahuan, pengalaman, ide dan teknik yang dimiliki kepada anggota lainnya
(Setiarso, 2013).

\section{Orientasi Pembelajaran}

Garvin (1993) dalam Prakosa dan Ghozali (2009) mendefinisikan tentang organizational learning merupakan proses dimana organisasi atau perusahaan belajar untuk bisa memiliki keahlian untuk mempelajari, menciptakan dan mentransfer pengetahuan serta sikap dari perusahaan untuk merefkelsikan hasil belajar yang dipelajari dari perusahaan.

\section{Inovasi}

Menurut Amabile dkk, (1996) dalam Suendro (2015) mendefinisikan inovasi sebagai konsepyang lebih luas yang membahas penerapan gagasan, produk atau proses yang baru. Sedangkan menurut Hurley dan Hult (1998) dalam Prakosa dan Ghozali (2009) inovasi yaitu suatu sistem mekanisme sebuah perusahaan untuk dapat beradaptasi dengan lingkungan yang dinamis.

\section{Hubungan Antar Variabel \\ Pengaruh Orientasi Pasar terhadap Inovasi}

Dengan inovasi, seseorang telah melakukan perubahan positif yang mengarah pada kemajuan.Pendapat tersebut memang benar adanya, tetapi bagi sebagian konsumen sesuatu sulit diterima begitu saja.Lukas dan Ferrell (2000) dalam penelitiannya menyatakan bahwa orientasi pasar berpengaruh positif terhadap inovasi. Sanjeev et al (2003) orientasi pasar memiliki hubungan positif terhadap inovasi produk.

Hasil penelitian Puspitasari (2015) menyatakan bahwa orientasi pasarberpengaruh positif terhadap inovasi.

$\mathrm{H}_{1} \quad$ Orientasi pasar berpengaruh terhadap inovasi

\section{Pengaruh Knowledge Sharing terhadap Inovasi}

Knowledge sharing (knowledge sharing) merupakan salah satu metode dalam 
knowledge management yang digunakan untuk memberikan kesempatan kepada perusahaan untuk saling berbagi ilmu pengetahuan, teknik, pengalaman dan ide yang mereka miliki kepada anggota lainnya. Semakin tinggi pemilik dan karyawan memiliki kesempatan yang luas dalam untuk menyampaikan sebuah pendapat, ide, kritikan, dan juga komentarnya kepada anggota lainnya, maka akan menjadi nilai tambah dan sekaligus melahirkan inovasi pada perusahaan.

Hasil dari penelitian Rismawati (2012) dan dan Djaya (2012) dalam menunjukkan bahwa terdapat hubungan yang positif dan signifikan antara knowledge sharing dengan inovasi..

$\mathrm{H}_{2}: \begin{aligned} & \text { Knowledge sharing berpengaruh } \\ & \text { terhadap inovasi }\end{aligned}$

\section{Pengaruh Orientasi Pembelajaran terhadap Inovasi}

Pembelajaran adalah pengetahuan dan wawasan baru yang yang dikembangkan berpotensi untuk mempengaruhi suatu prilaku (Sinkula, 1994, Narver and Slater, 1995.Dengan demikian pembelajaran terkait dengan kemampuan pembelajaran karyawan dalam suatu organisasi yaitu dengan melalui komitmen karyawan untuk dapat belajar, mempuunyai visi bersama serta berbagai pandangan. Semakin tinggi karyawan mempunyai kemampuan untuk belajar, maka juga semakin bertambah pengetahuan atau wawasan baru sehingga karyawan akan lebih bisa menciptakan ideide baru.

Hasil dari penelitian Stata (1989) dalam Hurley dan Hult (1998) mengatakan bahwa pembelajaran organisasi mempunyai pengaruh positif dengan inovasi.

$\mathrm{H}_{3}$ : Orientasi pembelajaran berpengaruh terhadap inovasi

\section{Pengaruh Orientasi Pasar terhadap Kinerja Bisnis}

Orientasi pasar merupakan proses dari menghasilkan dan memberikan sebuah informasi pasar bertujuan untuk menciptakan nilai pelanggan bagi konsumen. Dengan demikian orientasi pasar sebagai suatu konsep orientasi yang berfokus pada nilainilai tinggi bagi pelanggan. Dengan semakin tingginya derajat orientasi pasar maka juga akan semakin tinggi kinerja perusahaan.

Penelitian ini didukung oleh penelitian Prakosa dan Ghozali (2009) menyimpulkan bahwa faktor penentu perusahaan orientasi perusahaan tanpa memandang kondisi lingkungan eksternal sekalipun dimana perusahaan itu sedang beroperasi.

$\mathrm{H}_{4}$ : Orientasi pasar berpengaruh terhadap kinerja bisnis

\section{Pengaruh Knowledge Sharing terhadap Kinerja Bisnis}

Masalah knowledge sharing dalam suatu organisasi pada saat ini menjadi suatu isu yang penting baik di bidang bisnis maupun non-bisnis, karena semua kegiatan manusia sebenarnya adalah kegiatan berorganisasi. Tidak ada kegiatan yang akan berjalan lancar, jika tidak ada pengorganisasian dan pengelolaan yang baik, tidak ada manfaat atau keuntungan yang bisa diperoleh, jika sebuah organisasi tidak berjalan dengan baik. Setiap organisasi memiliki anggota, dimana masing-masing anggota bekerja berdasarkan pengetahuannya, maka mengelola pengetahuan akhirnya adalah yang mengelola anggota-anggota sendiri. Knowledge sharing dengan adanya organisasi akan memberikan kontribusi terhadap kinerja organisasi terutama pada peningkatan dalam kualitas layanan (Matzler et al, 2008).

Hasil penelitian penelitian Hamzah dan Djaya (2012) bahwa knowledge sharing mempunyai pengaruh yang signifikan terhadap kinerja perusahaan

$\mathrm{H}_{5}$ : Knowledge sharing berpengaruh terhadap kinerja bisnis

\section{Pengaruh Orientasi Pembelajaran terhadap Kinerja Bisnis}

Menurut Prakosa dan Ghozali (2009) bahwa orientasi pembelajaran merupakan 


\section{Kerangka Pemikiran}

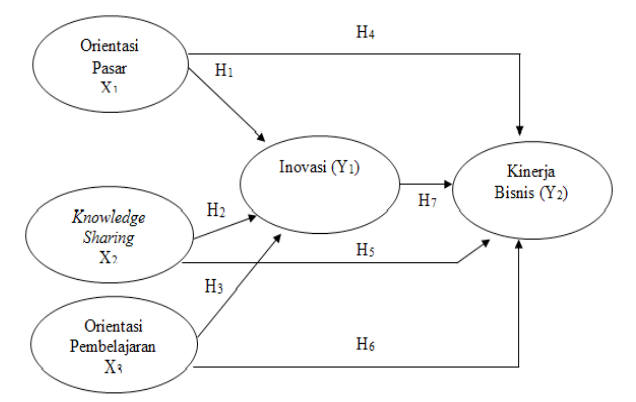

proses yang dilakukan perusahaan untuk memiliki keahlian dalam menciptakan, mempelajari dan mentransfer pengetahuan serta sikap dari perusahaan sebagai hasil dari pembelajaran masa lalu.

Hasil penelitian Suendro (2015) dan Sismanto (2015) menyatakan bahwa orientasi pembelajaran mempunyai pengaruh terhadap kinerja bisnis, yaitu dengan arah positif.

$\mathrm{H}_{6}$ : Orientasi pembelajaran berpengaruh terhadap kinerja bisnis

\section{Pengaruh Inovasi terhadap Kinerja bisnis}

Inovasi merupakan perubahan produk atau jasa untuk memperbaiki produk yang telah ada atau menambah banyaknya ragam produk atau jasa yang dihasilkan sehingga konsumen dapat memenuhi keinginannya dalam mendapatkan produk atau jasa yang dikehendaki sesuai dengan selera. Inovasi juga berpengaruh terhadap kinerja perusahaan dalam.Perusahaan yang berusaha mempergunakan sumber daya yang dimilikinya untuk dapat berinovasi. Anggota organisasi perusahaan berusaha untuk belajar demi kemajuan perusahaan. Dalam penelitiannya Han et al (1998) dalam Prakoso dan Bagas (2009) memaparkan bahwa inovasi secara positif dan juga signifikan berpengaruh terhadap kinerja perusahaan

Hasil penelitian Lestari, dkk (2015), Subiyanto (2014) menunjukkan bahwa inovasi mempunyai pengaruh terhadap kinerja karyawan.
$\mathrm{H}_{7}$ : Inovasi berpengaruh terhadap kinerja bisnis

\section{METODE PENELITIAN}

Penelitian ini bermaksud untuk menguji hipotesis dan memperkuat dugaan sementara dengan harapan membenarkan yang telah dirumuskan pada gilirannya dapat mendukung teori.Atas dasar dari asumsi tersebut, maka jenis penelitian ini yang digunakan yaitu explanatory research dengan melalui penelitian asosiatif, yaitu bertujuan untuk menjelaskan hubungan antara dua variabel atau lebih (Sugiyono, 2012).

\section{Populasi dan Sampel}

Populasinya adalah pemilik/pengusaha pada industri tepung tapioka di Kabupaten Pati sebesar 162 orang.

Untuk memberikan hasil yang akurat, maka jumlah sampel yang diambil dengan menggunakan rumus Slovin (Umar, 2012) sebagai berikut :

$$
\mathrm{n}=\frac{\mathrm{N}}{1-\mathrm{Ne}^{2}}
$$

Besarnya populasi diketahui sebesar 162 orang. Jadi besarnya sampel yang digunakan adalah:

$$
\begin{gathered}
=\frac{162}{1+162(0,1)^{2}} \frac{162}{1+(162) \times(0,01)} \\
\frac{162}{2,62}=61,8 \longrightarrow \mathrm{n}=62
\end{gathered}
$$

Berdasarkan perhitungan tersebut 
diatas, maka sampel dalam penelitian ini adalah pemilik atau pengusaha pada industri tepung tapioka di Kabupaten Pati sebanyak 62 responden.

Teknik sampling dalam penelitian ini adalah Simple Random Sampling, yaitu teknik yang digunakan apabila semua populasi mempunyai anggota atau unsur yang bersifat homogeny dan berstrata secara proposional.(Sugiyono, 2012).

\section{Uji Instrumen \\ Uji Validitas}

Untuk mengetahui kelayakan instrumen, maka kriteria pengambilan keputusan ditentukan dengan nilai $r$ hitung $>$ nilai $r$ tabel. Berikut hasil pengujian berdasarkan kriteria statistiknya :

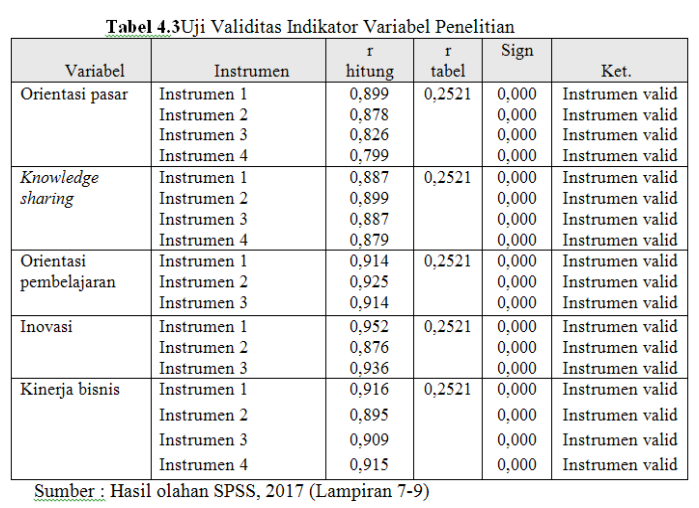

Pada masing-masing variabel orientasi pasar, knowledge sharing, orientasi pembelajaran, inovasi terhadap kinerja bisnis hasil yang diperoleh menunjukkan valid, terlihat pada semua indikator pada nilai hasil $r$ hitung telah melebihi dari nilai $r$ tabel sebesar 0,2521 dengan signifikansinya di bawah tingkat kesalahan sebesar 0,05 , sehingga masing-masing indikator pada masing-masing variabel memenuhi kelayakan.

\section{Uji Reliabilitas}

Orientasi pasar, knowledge sharing, orientasi pembelajaran, inovasi dan kinerja bisnis diperoleh nilai cronbanch alpha telah melebihi dari batas yang ditentukan sebesar 0,6 . Berdasarkan uraian tersebut di atas

Tabel 4.4Uji Reliabilitas Variabel Penelitian
\begin{tabular}{|l|c|c|c|}
\hline \multicolumn{1}{|c|}{ Variabel } & $\begin{array}{c}\text { Nilai } \\
\text { Crobanch Alpha }\end{array}$ & $\begin{array}{c}\text { Nilai } \\
\text { Standarisasi }\end{array}$ & Keterangan \\
\hline Orientasi pasar & 0,873 & 0,6 & Reliabel \\
Knowledge sharing & 0,908 & 0,6 & Reliabel \\
Orientasi pembelajaran & 0,902 & 0,6 & Reliabel \\
Inovasi & 0,910 & 0,6 & Reliabel \\
Kinerja bisnis & 0,929 & 0,6 & \\
& Reliabel \\
\hline
\end{tabular}
Sumber: Hasil olahan SPSS, 2017 (Lampiran 10-14)

bahwa nilaiCrobanch Alpha lebih besar dari batas yang ditentukan yaitu sebesar 0,6 yang berarti semua variabel dinyatakan reliabel, sehingga kuesioner tersebut dapat dilanjut untuk penelitian.

\section{Deskriptif Variabel}

Persepsi responden mengenai variabel yang di teliti, studi ini menggunakan kriteria rentang sebesar $5-1 / 3=1,33$ (Ghozali, 2006). Oleh karena itu intespretasi nilainya adalah sebagai berikut :
1. $1,00-2,33=$ Rendah
2. $2,33-3,66=$ Sedang
3. $3,67-5,00=$ Tinggi

\section{Variabel Orientasi Pasar}

Tabel 4.5Tanggapan Responden Variabel Orientasi Pasar
\begin{tabular}{|c|l|c|c|c|}
\hline No & \multicolumn{1}{|c|}{ Indikator } & Rata-rata & Kategori \\
& & $\begin{array}{c}\text { Standard } \\
\text { Deviasi }\end{array}$ & \\
\hline 1 & Interaksi dengan pelanggan & 3,80 & 0,996 & Tinggi \\
\hline 2 & Pengkajian perubahan pasar & 3,82 & 1,051 & Tinggi \\
\hline 3 & Tanggap perubahan harga pesaing & 3,65 & 0,936 & Sedang \\
\hline 4 & Mengkaji ulang produk & 3,73 & 0,887 & Tinggi \\
\hline & Rata-rata keseluruhan & 3,75 & & Tinggi \\
\hline
\end{tabular}
Sumber: Data primer vang diolah 2017 (Lampiran 2)

Tanggapan responden pada tabel 4.5 sebagian besar responden memberikan penilaian yang positif tentang peran pentingnya pemahaman orientasi pasar bagi pemilik/pengusaha. Hal tersebut terlihat dengan tingginya nilai rata-rata skor jawaban responden diperoleh sebesar 3,75 dan rataratanya yang melebihi dari standard deviasinya sehingga tanggapan tersebut berada dalam kategori tinggi.Dengan memahami orientasi pasar, maka pemilik/ pengusaha lebih memahami kebutuhan dan keinginan pelanggan baik pada saat ini maupun pada masa yang akan datang, apa 
yang diinginkan pada saat ini dan pada saat mendatang, serta apa yang dirasakan pada saat ini maupun yang dirasakan pada saat masa yang akan datang.

\section{Variabel Knowledge Sharing}

\begin{tabular}{|c|c|c|c|c|}
\hline No & Indikator & Rata-rata & $\begin{array}{c}\text { Standard } \\
\text { Deviasi }\end{array}$ & Kategori \\
\hline 1 & Rutinitas dalam diskusi & 3,65 & 0,903 & Sedang \\
\hline 2 & Bertukar pengalaman & 3,70 & 0,841 & Tinggi \\
\hline 3 & Kegiatan workshop & 3,64 & 0,777 & Sedang \\
\hline 4 & Seminar & 3,71 & 0,941 & Tinggi \\
\hline & Rata-rata keseluruhan & 3,68 & & Tinggi \\
\hline
\end{tabular}

Tanggapan respoden sebagaimana pada tabel 4.6 menunjukkan bahwa sebagian besar responden merespon positif tentang arti pentingnya pemilik/pengusaha untuk saling berbagi pengetahuan, terbukti dengan nilai skor sebesar 3,68 yang termasuk dalam kategori tinggi. Dengan adanya saling berbagi pengetahuan tentu akan mampu mengkomunikasikan pengetahuannya kepada pihak lain dalam perusahaan dengan baik, sehingga dapat terintegrasi dengan baik sehingga tentu akan mempengaruhi capaian yang dihasilkan

\section{Variabel Orientasi Pembelajaran}

\begin{tabular}{l} 
Tabel 4.7Tanggapan Responden Variabel Orientasi Pembelajaran \\
\begin{tabular}{|c|l|c|c|c|}
\hline No & \multicolumn{1}{|c|}{ Indikator } & Rata-rata & $\begin{array}{c}\text { Standard } \\
\text { Deviasi }\end{array}$ & Kategori \\
\hline 1 & Komitmen untuk belajar & 3,61 & 0,943 & Sedang \\
\hline 2 & Visi yang jelas & 3,80 & 0,789 & Tinggi \\
\hline 3 & Pembelajarankaryawan & 3,74 & 0,933 & Tinggi \\
\hline & Rata-rata keseluruhan & 3,72 & & Tinggi \\
\hline
\end{tabular} \\
\hline
\end{tabular}

Tanggapan responden terhadap orientasi pembelajaran sebagian besar responden memberikan penilaian yang baik tentang arti pentingnya bagi pemilik/pengusaha untuk terus melakukan orientasi pembelajaran, terlihat dengan nilai rata-rata nilai skor jawaban responden $p$ sebesar 3,72 yang termasuk dalam kategori tinggi. Dengan melakukan orientasi pembelajaran, maka pemilik/pengusaha akan memiliki keahlian dalam menciptakan, mempelajari dan mentransfer pengetahuan serta sikap dari perusahaan sebagai hasil dari pembelajaran masa lalu. Pembelajaran masa lalu dapat dijadikan pengalaman untuk bekerja lebih baik.

\section{Variabel Inovasi}

Tabel 4.8Tanggapan Responden Variabel Inovasi
\begin{tabular}{|c|c|c|c|c|}
\hline No & Indikator & Rata-rata & Kategori \\
& & 3,70 & 0,859 & Tinggi \\
\hline 1 & Ide baru tentang harga & 3,74 & 0,900 & Tinggi \\
\hline 2 & Ide baru tentang produk & 3,80 & 0,915 & Tinggi \\
\hline 3 & Ide baru tentang distribusi & 3,75 & & Tinggi \\
\hline & Rata-rata keseluruhan & Sumber : Data primer yang diolah 2017 (Lampiran 5) \\
\hline
\end{tabular}

Tanggapan responden terhadap inovasi sebagian besar responden memberikan penilaian yang sangat tinggi tentang peran pentingnya bagi pihak pemilik/pengusaha untuk melakukan inovasi produk, terlihat dengan rata-rata skor jawaban sebesar 3,75 yang lebih besar dari standar deviasinya yang termasuk dalam kategori tinggi. Oleh karena itu pemilik/pengusaha ddituntut untuk menciptakan inovasi-inovasi baru terhadap produk yang ditawarkan sehingga akan menambah ketertarikan pelanggannya

\section{Variabel Kinerja Bisnis}

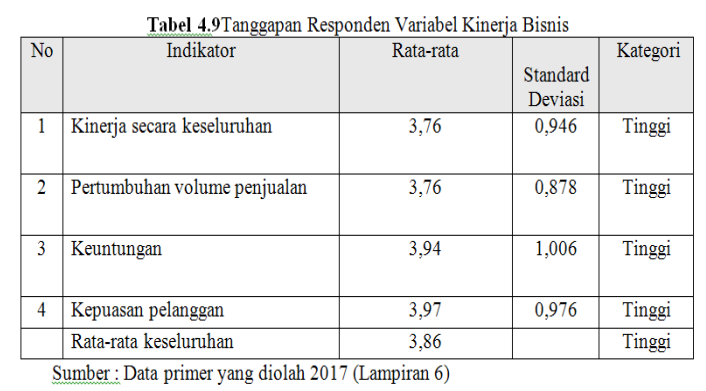

Sebagian besar responden memberikan penilaian positif bagi pihak pemilik/ pengusaha dalam memajukan kinerja bisnis, dengan skor jawaban sebesar 3,86 yang berada di atas nilai standard deviasi yang berada dalam kategori tinggi.Untuk tanggapan tertinggi yaitu pada indikator kepuasan pelanggan dengan skor sebesar 3,97 , sedangkan untuk tanggapan terendah 
yaitu pada indikator kinerja secara keseluruhan dan pertumbuhan volume penjualan dengan nilai rata-rata jawaban responden sebesar 3,76. Tingginya tanggapan tersebut memberikan indikasi bahwa dengan adanya evaluasi kinerja bisnis, maka dapat digunakan untuk mengevaluasi hasil kerja yang dilakukan pihak pemilik/pengusaha sudah sejalan dengan tujuan yang diharapkan atau belum. Keberadaan pemilik/pengusaha dalam melakukan usaha adalah untuk mencapai tujuan tertentu yang sudah ditetapkan sebelumnya, sehingga informasi tentang tentang penilaian kinerja merupakan suatu hal yang sangat penting dalam memajukan usahanya.

\section{Uji Asumsi Klasik}

\section{Uji Normalitas}

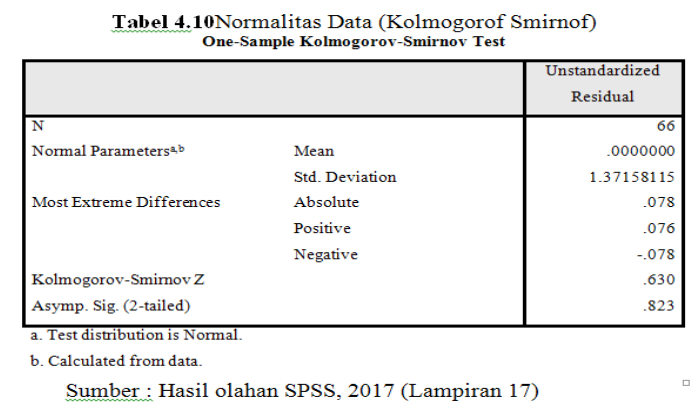

Hasil pengujian normalitas data menunjukkan bahwa untuk masing-masing variabel variable orientasi pasar, knowledge sharing, orientasi pembelajaran, inovasi terhadap kinerja bisnis berdistribusi normal, terbukti dengan nilai signifikansinya sebsar 0,8238 telah melebihi batas signifikansi sebesar 0,05. Dengan demikian pengujian pada variabel penelitian berdistribusi normal sehingga pengujian dapat dilanjutkan pada pengujian selanjutnya..

\section{Multikolinearitas}

Hasil yang diperoleh pada pengujian multikolinieritas pada variabel orientasi pasar, knowledge sharing, orientasi pembelajaran, inovasi terhadap kinerja bisnis menunjukkan bahwa semua nilai tolerance lebih besar dari nilai default 0,10.
Tabel 4.11Uji Multikolonieritas

\begin{tabular}{|c|c|c|c|lc|}
\hline No & $\begin{array}{c}\text { Variabel } \\
\text { Penelitian }\end{array}$ & Tolerance & VIF & \multicolumn{2}{|c|}{ Keterangan } \\
\hline 1 & Orientasi pasar & 0,346 & 2,893 & $\begin{array}{l}\text { Tidak terjadi } \\
\text { multikolinieritas }\end{array}$ & problem \\
\hline 2 & Knowledge sharing & 0,351 & 2,852 & $\begin{array}{l}\text { Tidak terjadi } \\
\text { multikolinieritas }\end{array}$ & problem \\
\hline 3 & $\begin{array}{l}\text { Orientasi } \\
\text { pembelajaran }\end{array}$ & 0,329 & 3,042 & $\begin{array}{l}\text { Tidak terjadi } \\
\text { multikolinieritas }\end{array}$ & problem \\
\hline 4. & Inovasi & 0,302 & 3,315 & $\begin{array}{l}\text { Tidak terjadi } \\
\text { multikolinieritas }\end{array}$ & problem \\
\hline
\end{tabular}

Sedangkan untuk nilai VIF juga menunjukkan di bawah angka 10, sehingga dapat disimpulkan bahwa semua variabel telah memenuhi persyaratan ambang toleransi dan nilai VIF, artinya bahwa variabel yang digunakan dalam penelitian ini tidak terjadi problem multikolinieritas.

\section{Heteroskedastisitas}

Tabel 4.12Uji Heteroskedastisitas (Uji Glejser)

\begin{tabular}{|c|c|c|c|}
\hline Tabel 4.12Uji Heteroskedastisitas (Uji Glejser) \\
\hline No & $\begin{array}{c}\text { Variabel } \\
\text { Penelitian }\end{array}$ & Sign & Keterangan \\
\hline 1 & Orientasi pasar & 0,391 & $\begin{array}{c}\text { Tidak terjadi problem } \\
\text { heteroskedastisitas }\end{array}$ \\
\hline 2 & Knowledge sharing & 0,186 & $\begin{array}{c}\text { Tidak terjadi problem } \\
\text { heteroskedastisitas }\end{array}$ \\
\hline 3 & Orientasi pembelajaran & 0,114 & $\begin{array}{c}\text { Tidak terjadi problem } \\
\text { heteroskedastisitas }\end{array}$ \\
\hline 4 & Inovasi & 0,902 & $\begin{array}{c}\text { Tidak terjadi problem } \\
\text { heteroskedastisitas }\end{array}$ \\
\hline
\end{tabular}

Berdasarkan Tabel 4.12 menunjukkan bahwa variabel orientasi pasar, knowledge sharing, orientasi pembelajaran, inovasi terhadap kinerja bisnis tidak terjadi problem heterokedastisitas. Hal ini dibuktikan dengan nilai signifikansi telah melebihi dari batas ketentuan sebesar 0,05 , sehingga disimpulkan bahwa pada uji ini tidak terjadi problem heterokedastisitassehingga pengujian telah memenuhi persyaratan dan dapat dilakukan pada pengujian selanjutnya.

\section{Regresi dengan Metode Path Analysis}

\begin{tabular}{|c|c|c|c|c|c|c|}
\hline \multicolumn{7}{|c|}{\begin{tabular}{|l|l|l|} 
Varialel & Variabel Bebas & $\mathrm{t}$ \\
\end{tabular}} \\
\hline & $\begin{array}{l}\text { Variabel } \\
\text { Terikat }\end{array}$ & Variabel Bebass & $\begin{array}{c}\mathrm{t} \\
\text { littumg }\end{array}$ & B & Sig & Keterangan \\
\hline \multirow[t]{3}{*}{1} & Inovasi & Orientasi pasar & 2,917 & 0,325 & 0,005 & Ha diterima \\
\hline & produlk & Knowledge sharing & 2,008 & 0,229 & 0,049 & Ha diterima \\
\hline & & Orientasi pembelajaran & 3,274 & 0,368 & 0,002 & Ha diterima \\
\hline \multirow[t]{4}{*}{2} & Kinerja & Orientasi pasar & 2,998 & 0,259 & 0,004 & Ha diterima \\
\hline & bisnis & Knowledge sharing & 2,119 & 0,182 & 0,038 & Ha diterima \\
\hline & & Orientasi pembelajaran & 2,048 & 0,181 & 0,045 & Ha diterima \\
\hline & & Inovasi & 4,262 & 0,394 & 0,000 & Ha diterima \\
\hline
\end{tabular}

Sumber : hasil olahan SPSS, 2017 (Lampiran 16 dan 17)

Berdasarkan persamaan regresi pengaruh 
tidak langsung antara orientasi pasar, knowledge sharing dan orientasi pembelajaran terhadap kinerja bisnis dengan inovasi sebagai variabel intervening dapat dijelaskan pada persamaan regresi sebagai berikut:

$Y_{1}=0,325 X_{1}+0,229 X_{2}+0,368 X_{3}$ $Y_{2}=0,259 X_{1}+0,182 X_{2}+0,181 X_{3}+0,394 Y_{1}$

\section{Pengujian Hipotesis \\ Pengaruh Orientasi Pasar Terhadap Inovasi}

Hasil pengujian orientasi pasar terhadap inovasi diperoleh nilai t hitung sebesar 2,917 dengan nilai signifikansi sebesar 0,005 < 0,05 . Pada taraf signifikansi 0,05 dan degres of freedom (df) sebesar 62, maka diperoleh nilai $t$ tabel sebesar 1,9990 , sehingga nilai $t$ hitung 2,917 $>$ nilai t tabel $=1,9990$ sehingga Ho ditolak dan Ha diterima. Hasil tersebut dapat diartikan bahwa terdapat pengaruh positif dan signifikan antara orientasi pasar terhadap inovasi.Dengan hasil pengujian tersebut maka pengujian mampu menerima hipotesis pertama, sehingga dugaan adanya pengaruh antara orientasi pasar terhadap inovasi terbukti atau dapat diterima.

\section{Pengaruh Knowledge Sharing terhadap Inovasi}

Hasil pengujian knowledge sharing terhadap inovasi diperoleh nilai $t$ hitung sebesar 2,008 dengan nilai signifikansi sebesar $0,049<0,05$, sehingga nilai $t$ hitung $=2,008>$ nilai $\mathrm{t}$ tabel $=1,9990$ yang berarti Ho ditolak dan Ha diterima. Penjelasan tersebut dapat diartikan bahwa knowledge sharing mempunyai pengaruh positif terhadap inovasi.Berdasarkan hasil pengujian dapat disimpulkan bahwa pengujian mampu menerima hipotesis kedua, sehingga dugaan adanya pengaruh antara knowledge sharing terhadap inovasi terbukti atau dapat diterima.

\section{Pengaruh Orientasi Pembelajaran terhadap Inovasi}

Hasil pengujian hipotesis ketiga antara orientasi pembelajaran terhadap inovasi diperoleh nilai t hitung sebesar 3,274 dengan nilai signifikansi sebesar 0,002 $<0,05$, sehingga nilai thitung $=3,274$ telah melebihi dari nilai $t$ tabel 1,9990 sehingga pengujian mampu menolak Ho dan menerima Ha. Penjelasan tersebut dapat diartikan bahwa orientasi pembelajaran berpengaruh positif terhadap inovasi.Berdasarkan hasil pengujian dapat disimpulkan bahwa pengujian tersebut mampu menerima hipotesis ketiga, sehingga dugaan adanya pengaruh tersebut dapat diterima atau terbukti.

\section{Pengaruh Orientasi Pasar terhadap Kinerja Bisnis}

Pada pengujian pengaruh langsung antara orientasi pasar terhadap kinerja bisnis diperoleh. nilai t hitung sebesar 2,998 dengan nilai signifikansi sebesar 0,004 < 0,05 , sedangkan pada taraf signifikansi 0,05 dan degres of freedom (df) sebesar 61, maka diperoleh nilai t tabel sebesar 1,9996, sehingga nilai t hitung $=2,998>1,9996$ yang berarti Ho ditolak dan Ha diterima artinya orientasi pasar mempunyai pengaruh positif terhadap kinerja bisnis. Hasil pengujian dapat disimpulkan bahwa pengujian tersebut mampu menerimahipotesiskeempat, sehingga dugaan yang menyatakan adanya pengaruh positif antara orientasi pasar terhadap kinerja bisnis terbukti atau dapat diterima.

\section{Pengaruh Knowledge Sharing terhadap Kinerja Bisnis}

Hasil pengujian antara knowledge sharing terhadap kinerja bisnis diperoleh nilai $t$ hitung sebesar 2,119 dengan nilai signifikansi sebesar $0,038<0,05$. Dengan demikian nilai $t$ hitung sebesar 2,119 >nilai $\mathrm{t}$ tabel $=1,9996$ yang berarti Ho ditolak dan $\mathrm{Ha}$ diterima. Dengan hasil tersebut maka dapat diartikan bahwa knowledge sharing mempunyai pengaruh positif terhadap kinerja bisnis. Dengan demikian pengujian mampu menerima hipotesis kelima, 
sehingga dugaan tersebut terbukti atau dapat diterima.

\section{Pengaruh Orientasi Pembelajaran terhadap Kinerja Bisnis}

Hasil pengujian orientasi pembelajaran terhadap kinerja bisnis diperoleh nilai t hitung sebesar 2,048 dengan nilai signifikansi sebesar $0,045<0,05$, sehingga nilai t hitung $2,048>$ nilai $t$ tabel sebesar 1,9996 yang berarti Ho ditolak dan Ha diterima. Hasil pengujian tersebut dapat diartikan bahwa pengujian mampu menerima hipotesis keenam, yang berarti orientasi pembelajaran mempunyai pengaruh positif dan signifikan terhadap kinerja bisnis.Berdasarkan hasil pengujian dapat disimpulkan bahwa dugaan adanya pengaruh orientasi pembelajaran terhadap kinerja bisnis terbukti atau dapat diterima.

\section{Pengaruh Inovasi terhadap Kinerja Bisnis}

Hasil pengujian inovasi terhadap kinerja bisnis diperoleh nilai t hitung sebesar 4,262 dengan nilai signifikansi sebesar 0,000 $<0,05$, sehingga nilai $\mathrm{t}$ hitung $=4,262$ telah melebihi dari nilai $\mathrm{t}$ tabel sebesar 1,9996. Penjelasan tersebut dapat diartikan bahwa inovasi mempunyai pengaruh positif dan signifikan terhadap kinerja bisnis.Berdasarkan hasil pengujian dapat disimpulkan bahwa pengujian mampu menerima hipotesis ketujuh, sehingga dugaan adanya pengaruh antara inovasi terhadap kinerja bisnis terbukti atau dapat diterima.

\section{Uji Koefisien Determinasi}

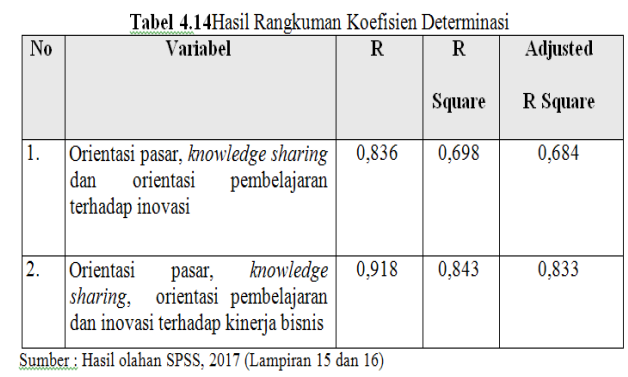

Berdasarkan tabel 4.14 menunjukkan ahwa nilai koefisien determinasi dapat dijelaskan sebagai berikut:

Nilai koefisien determinasi antara orientasi pasar, knowledge sharing dan orientasi pembelajaran terhadap inovasi yang ditunjukkan dengan nilai Adjusted $R$ Square sebesar 0,684 , dapat diartikan bahwa inovasi mampu dijelaskan oleh ketiga variable yaitu orientasi pasar, knowledge sharing dan orientasi pembelajaran sebesar $68,4 \%$ sedangkan sisanya dijelaskan oleh variabel lain yang tidak diamati dalam penelitian ini.

Nilai koefisien determinasi antara orientasi pasar, knowledge sharing, orientasi pembelajaran dan inovasi terhadap kinerja bisnis ditunjukkan dengan nilai Adjusted $R$ Square sebesar 0,833 , dapat diartikan bahwa kinerja bisnis mampu dijelaskan oleh keempat variabel yaitu orientasi pasar, Knowledge sharing, orientasi pembelajaran dan inovasi sebesar $83,3 \%$ sedangkan sisanya dijelaskan oleh variabel lain yang tidak diamati dalam penelitian ini.

\section{Uji Sobel Test}

Untuk mengetahui inovasi mampu menjadi variabel intervening antara orientasi pasar, knowledge sharing dan orientasi pembelajaran terhadap kinerja bisnis, maka dalam penelitian ini menggunakan uji sobel test dengan calculation for the sobel test. Adapun kriteria dikatakan mampu menjadi variabel intervening dapat dilihat pada two tailed probability nilai p-value < taraf signifikansinya 0,05 , yang berarti Ho ditolak dan Ha diterima yang berarti pengujian mampu menjadi variabel intervening. Untuk dapat mengetahui lebih jelas dilihat pada gambar

berikut:

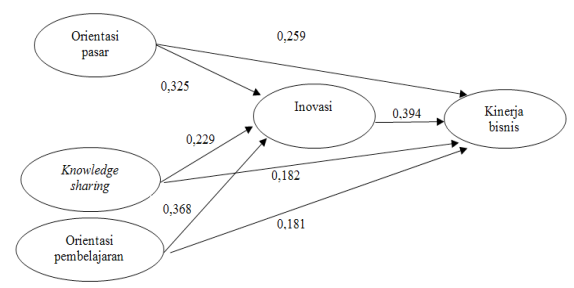

Gambar 4.1Analisis Jalur Antar Variabel Penelitian 


\section{Pengaruh Orientasi Pasar Terhadap Kinerja Bisnis melalui Inovasi}

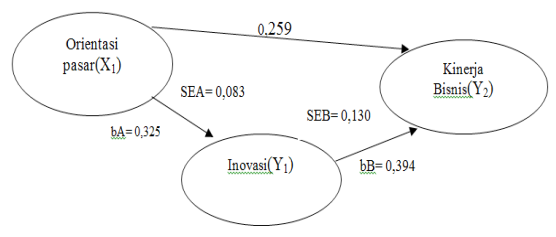

Gambar 4.2 Uji Mediasi Orientasi Pasar terhadap Kinerja Bisnis melalui Inovasi

Hasil pengujian sobel test antara orientasi pasar terhadap kinerja bisnis dengan inovasi sebagai variabel intervening, maka diperoleh nilai sobel test statisticnya sebesar 2,397 > 1,96 dan pada two tailed probability diperoleh nilai signifikansi sebesar 0,0165 $<0,05$ (Lampiran19). Dengan hasil pengujian tersebut maka dapat disimpulkan bahwa inovasi mampu menjadi variabel intervening antara orientasi pasar terhadap kinerja bisnis.

\section{Pengaruh Knowledge Sharing terhadap Kinerja Bisnis melalui Inovasi}

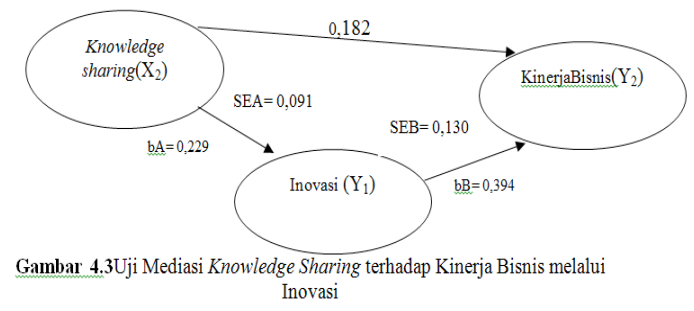

Hasil pengujian sobel test antara knowledge sharing terhadap kinerja bisnis melalui inovasi diperoleh nilai sobel test Statisticnya sebesar 1,936 < 1,96 dan pada two tailed probability diperoleh nilai signifikansisebesar 0,053 (Lampiran 19) yang berarti lebih besar dari tingkat kesalahan sebesar 0,05, sehingga dapat disimpulkan bahwa inovasi tidak mampu menjadi variabel intervening antara knowledge sharing dengan kinerja bisnis. Dengan demikian knowledge sharing hanya berpengaruh terhadap kinerja bisnis saja tidak melalui inovasi produk.
Pengaruh Orientasi Pembelajaran terhadap Kinerja Bisnis melalui Inovasi

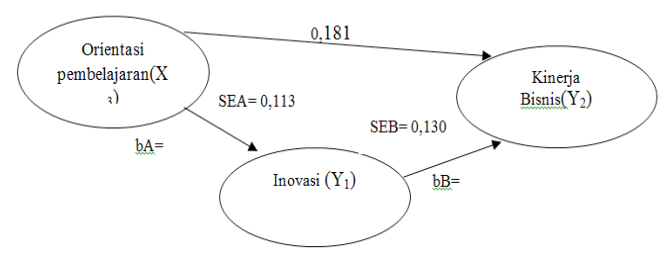
Gambar 4.4Uji Mediasi Orientasi Pembelajaran terhadap Kinerja Bisnis melalui
Inovasi

Hasil pengujian pengaruh tidak langsung antara pengaruh orientasi pembelajaran terhadap inovasi menuju ke kinerja bisnis setelah dilakukan pengujian diperoleh nilai sobel test Statisticnya sebesar 2,218 dan pada two tailed probability diperoleh nilai signifikansi sebesar 0,026 (Lampiran 20) yang berarti lebih kecil dari tingkat kesalahan sebesar 0,05 yang dapat disimpulkan bahwa inovasi mampu menjadi variabel intervening antara orientasi pembelajaran dengan kinerja bisnis.

\section{PEMBAHASAN}

\section{Pengaruh Orientasi Pasar terhadap Inovasi}

Hasil pengujian menunjukkan orientasi pasar mempunyai pengaruh positif terhadap inovasi, artinya semakin tinggi orientasi pasar, Maka pengkajian perubahan pasar sangat diperlukan bagi pemilik/pengusaha guna menciptakan kreativitas untuk menemukan ide baru tentang distribusi.

Bagi perusahaan interaksi dengan pelanggan sangat diperlukan karena dengan adanya interaksi akan tercipta ide-ide baru tentang produk yang diinginkan pelanggan. Pemilik/pengusaha secara periodik perlu melakukan pengkajian ulang terhadap produk yang dihasilkan sehingga ide baru akan muncul tentang penetapan harga. Daya tanggap perubahan harga pesaing dapat menjadi evaluasi bagi pemilik/pengusaha dalam memunculkan ide-ide baru yang lebih kreatif dalam menetapkan harga. 


\section{Pengaruh Knowledge Sharing terhadap Inovasi}

Knowledge sharing berpengaruh positif terhadap inovasi, artinya bahwa semakin pemilik/pengusaha mampu berbagi pengetahuan kepada anggota lainnya, maka akan semakin menciptakan inovasi produk baru. Keterlibatan pemilik/pengusaha dalam mengikuti seminar dapat membantu memunculkan ide-ide baru terutama dalam menangani permasalahan distribusi produk.

Adanya keinginan untuk senantiasa bertukar pengalaman dengan sesama tim kerja akan memunculkan ide-ide baru tentang produk yang dihasilkan. Penting bagi pemilik/pengusaha untuk melakukan diskusi secara rutin guna memunculkan ide-ide baru terkait dengan penetapan harga produk. Keaktifan pemilik/pengusaha sangat diperlukan yaitu melalui kegiatan workshop sehingga memunculkan ide-ide baru tentang harga yang dijual.

\section{Pengaruh Orientasi Pembelajaran terhadap Inovasi}

Orientasi pembelajaran mempunyai pengaruh positif terhadap inovasi, memberikan pengertian bahwa semakin tinggi pemilik/pengusaha mempunyai kemampuan untuk belajar, maka akan semakin menciptakan inovasi produk baru. Tim kerja yang solid dengan mempunyai visi yang jelas dalam memajukan usaha akan berguna dalam memunculkan ideide tentang distribusi yang dilakukan perusahaan.

Penting bagi pemilik/pengusaha mempunyai prioritas dalam melakukan pembelajaran sehingga mampu memunculkan ide-ide

\section{Pengaruh Orientasi Pasar terhadap Kinerja Bisnis}

Orientasi pasar berpengaruh positif terhadap kinerja bisnis, dapat diartikan bahwa semakin tinggi orientasi pasar, maka pemilik/pengusaha mampu berinteraksi langsung dengan pelanggan sehingga akan meningkatkan kinerja bisnis yang dihasilkan. Penting bagi pemilik/ pengusaha untuk melakukan pengkajian perubahan pasar untuk menjamin bahwa produk yang diproduksinya sesuai dengan keinginan pelanggan, sehingga hal itu akan mempengaruhi tingginya kepuasan pelanggan.

\section{Pengaruh Knowledge Sharing terhadap Kinerja Bisnis}

Knowledge sharing berpengaruh positif terhadap kinerja bisnis, yang berarti bahwa semakin tinggi pemilik/pengusaha berbagi pengetahuan kepada anggota lainnya, maka akan semakin meningkatkan kinerja bisnis yang dihasilkan. Inovasi dapat tercipta karena adanya keinginan untuk senantiasa bertukar pengalaman dengan sesama tim kerja sehingga akan mempengaruhi tingkat keuntungan yang diperoleh perusahaan.

\section{Pengaruh Orientasi Pembelajaran terhadap Kinerja Bisnis}

Orientasi pembelajaran berpengaruh positif terhadap kinerja bisnis, artinya semakin tinggi pemilik/pengusaha mempunyai kemampuan untuk belajar, maka akan semakin meningkatkan kinerja bisnis yang dihasilkan. Keberhasilan kinerja bisnis ditentukan oleh tim kerja yang solid dengan mempunyai visi yang jelas dalam memajukan usaha terkait harapan dan keinginan pelanggan, sehingga tentu akan mempengaruhi kepuasan pelanggan.

\section{Pengaruh Inovasi terhadap Kinerja Bisnis}

Inovasi mempunyai pengaruh signifikan positif terhadap kinerja bisnis, artinya semakin pemilik/pengusaha mampu menciptakan inovasi produk, maka akan semakin meningkatkan kinerja bisnis yang dihasilkan. Artinya bahwa untuk menciptakan inovasi produk maka dibutuhkan agresifitas dari pemilik/pengusaha dalam mencari dan menemukan ide-ide baru, seperti tentang harga produk baru yang akan dijual dalam 
pencapaian kinerja yang maksimal.

\section{Pengaruh Langsung dan Tidak Langsung}

Berdasarkan hasil pengujian sobel test, terlihat bahwa inovasi mampu menjadi variabel intervening antara orientasi pasar dengan kinerja bisnis.

Inovasi tidak mampu menjadi variabel intervening antara knowledge sharing dengan kinerja bisnis.Dengan demikian knowledge sharing hanya berpengaruh terhadap kinerja bisnis tetapi tidak melalui inovasi produk.Hal ini dapat diartikan bahwa semakin tinggi pemilik/pengusaha memiliki kesempatan yang luas dalam menyampaikan pendapat, ide, kritikan, dan komentarnya kepada anggota lainnya hanya mampu meningkatkan kinerja bisnis yang dihasilkan, tetapi tidak harus melalui inovasi.

\section{SIMPULAN}

Berdasarkan penelitian yang telah dilakukan maka dapat diperoleh kesimpulan sebagai berikut :

Orientasi pasar terbukti mempunyai pengaruh positif terhadap inovasi, dapat diartikan bahwa semakin tinggi orientasi pasar, maka pemilik/pengusaha dapat mengetahui, memahami serta menjawab kebutuhan maupun harapan dari pelanggan, sehingga pemilik/pengusaha dapat menciptakan inovasi produk baru.

Knowledge sharing terbukti mempunyai pengaruh positif terhadap inovasi, dapat diartikan bahwa semakin tinggi pemilik/ pengusaha memiliki kesempatan yang luas dalam menyampaikan pendapat, ide, kritikan, dan komentarnya kepada anggota lainnya, maka pemilik/pengusaha dapat menciptakan inovasi produk baru.

Orientasi pembelajaran mempunyai pengaruh positif terhadap inovasi, dapat diterjemahkan bahwa semakin tinggi pemilik/ pengusaha mempunyai kemampuan untuk belajar, maka akan semakin bertambah pengetahuan atau wawasan baru sehingga akan dapat menciptakan inovasi produk baru.

Orientasi pasar mempunyai pengaruh positif terhadap kinerja bisnis, memberikan pengertian bahwa semakin tinggi orientasi pasar, maka pemilik/pengusaha dapat mengetahui, memahami serta menjawab kebutuhan maupun harapan dari pelanggan, sehingga akan meningkatkan kinerja bisnis yang dihasilkan.

Knowledge sharing mempunyai pengaruh positif terhadap kinerja bisnis, dapat diartikan bahwa semakin tinggi pemilik/ pengusaha memiliki kesempatan yang luas dalam menyampaikan pendapat, ide, kritikan, dan komentarnya kepada anggota lainnya, maka akan semakin meningkatkan kinerja bisnis yang dihasilkan.

Orientasi pembelajaran mempunyai pengaruh signifikan positif terhadap kinerja bisnis, dapat diartikan bahwa semakin tinggi pemilik/pengusaha mempunyai kemampuan untuk belajar, maka akan semakin bertambah pengetahuan atau wawasan baru sehingga akan semakin meningkatkan kinerja bisnis yang dihasilkan.

Inovasi mempunyai pengaruh positif terhadap kinerja bisnis, dapat diartikan bahwa semakin pemilik/pengusaha mampu menciptakan inovasi produk baru, maka akan semakin meningkatkan kinerja bisnis yang dihasilkan.

Inovasi mampu menjadi variabel intervening antara orientasi pasar dengan kinerja bisnis

Inovasi tidak mampu menjadi variabel intervening antara knowledge sharing dengan kinerja bisnis. Dengan demikian knowledge sharing hanya berpengaruh terhadap kinerja bisnis tetapi tidak melalui inovasi produk.

Inovasi mampu menjadi variabel intervening antara orientasi pembelajaran dengan kinerja bisnis, dapat diartikan semakin tinggi pemilik/pengusaha mempunyai kemampuan untuk belajar, maka akan semakin bertambah pengetahuan atau wawasan baru sehingga akan dapat 
menciptakan inovasi produk baru sehingga mampu meningkatkan kinerja bisnis

Perlu adanya upaya dari pihak pemilik/ pengusaha untuk lebih kreatif dalam menciptakan ide-ide baru tentang produk sesuai keinginan pelanggan

Agar dapat memenuhi kebutuhan dan keinginan pelanggan, maka pihak pemilik/pengusaha mampu menyesuaikan perubahan harga yang dilakukan pesaing.

Hendaknya pihak pemilik/pengusaha agar dapat berbagi pengetahuan dengan karyawan, maka diperlukan wawasan dan pengetahuan yang luas dari pemilik/ pengusaha yaitu dengan melakukan kegiatan workshop
Hendaknya ada upaya dari pihak pemilik/ pengusaha untuk mempunyai komitmen yang tinggi dalam memajukan perusahaan

Teknik pengumpulan data yang dipakai dalam penelitian ini hanya menggunakan kuesioner sehingga kesimpulan yang dapat diambil hanya berdasarkan pada data yang dikumpulkan melalui kuesioner tersebut.Data yang dianalisis merupakan persepsi jawaban responden yang dapat menimbulkan masalah jika jawaban responden tidak sesuai dengan keadaan yang sesungguhnya. Untuk itu pada penelitian selanjutnya sebaiknya ditambah dengan teknik wawancara sehingga akan lebih memperkuat keakuratan data

\section{DAFTAR PUSTAKA}

Chasanah, Nur. (2009). Analisis Pengaruh Empowerment, Self Efficacy Dan Budaya Organisasi Terhadap Kepuasan Kerja Dalam Meningkatkan Kinerja Karyawan. Tesis, Universitas Diponegoro Semarang

Daft, R. (2009). Organization Theory and Design, 10th ed., South-Western College Publishing, Cincinnati, $\mathrm{OH}$.

Dewi, Putu Eka Purnama dan I Gusti Ayu Manuati Dewi. (2015). Pengaruh Self Efficacy Dan Motivasi Kerja Pada Kepuasan Kerja Karyawan Happy Bali Tour Dan Travel Denpasa. Jurnal Manajemen Strategi Bisnis dan Kewirausahaan, 9 (1).

Fitrasani. (2009). Knowledge Acquisition pada Knowledge Based Economy ERA, So,psoi, Masopma, System Teknologi Informasi. Universitas Gajah Mada : Yogyakarta.

Ghozali, Imam. (2011). Aplikasi Analisis Multivariate bagi Program SPSS. Badan Penerbit : UNDIP.

Lestari, Indah Puji, dkk. (2015). Pengaruh Self Efficacy Dan Organizational Citizenship Behavior Terhadap Kinerja Pegawai Dengan Kepuasan Kerja Sebagai Variabel Intervening. Artikel IImiah Mahasiswa

Prakosa, Bagus dan Ghozali, Imam. (2009). Pengaruh Orientasi Pasar, Inovasi, dan Orientasi Pembelajaran terhadap Kinerja Perusahaan untuk Mencapai Keunggulan Bersaing (Studi Empiris pada Industri Manufaktur di Semarang. EKOBIS V 6 (2) : 181 - 198.

Puspitasari, Ratih Hesty Utami. (2015). Orientasi pasar dan inovasi produk sebagai strategi untuk meningkatkan kinerja pemasaran perusahaan mebel Jepara. Prosiding Seminar Nasional Kebangkitan Teknolgi.

Salangka, Rian dan Lucky Datulong. (2015). Pengaruh self efficacy, self esteem dan lingkungan kerja terhadap kepuasan kerja karyawan pada PT, PLN Wilayah Suluttenggo. Jurnal EMBA, 3 (3) : 562-572, ISSN 2303-11

Sugiyono. (2012). Metodologi Penelitian, Alfa Beta : Jakarta.

Sulistiyani. (2013). Pengaruh orientasi pasar dan kreativitas program pemasaran serta pengaruhnya terhadap kinerja usaha kecil dan menengah di Kota Semarang. Proceding 
Seminar Nasional dan Call For papers Sancall, ISBN:978-979-636-147-2

Umar, Husein. (2012). Metodologi Penelitian, Gramedia Pustaka Utama : Jakarta. 